\title{
The effects of variations in the implementation of a stepwise managerial strategic crisis model and corporate reputation capital on post-crisis share price values: A qualitative and quantitative analyses of specific South African companies
}

\author{
D. A. L. Coldwell ${ }^{1 \star}$ and T. Joosub ${ }^{2}$ \\ ${ }^{1}$ School of Economic and Management Sciences, University of the Witwatersrand, Johannesburg, South Africa. \\ ${ }^{2}$ School of Accountancy, University of the Witwatersrand, Johannesburg, South Africa.
}

Accepted 1 August, 2011

\begin{abstract}
The paper proposes a structured, st e p w i s e approach to the management of reputational risks in order to assist in defining strategies for crisis management. A series of case studies of selected South African firms' responses to specific crises in comparison to an ideal type stepwise model were analyzed and the effects on specific share price values explored. The effect of reputation capital on share price values, six months after the crises each of the selected companies sustained was also investigated. Correlation analyses tentatively indicated that the number of steps taken by management in the companies concerned in conformance with the model, and the speed with which they were implemented, affected post-crisis average share price values. Corporate capital as measured by perceptions of reputation and brand strength, were also found to be associated with greater company post-crisis share price resolution.
\end{abstract}

Key words: Crisis management, ideal type model, case study analysis, share price, reputation capital.

\section{INTRODUCTION}

A negative corporate event or crisis may, in many cases, cause investors to react, negatively with serious implications for the value of the firm. The ability of a company to maintain a good reputation is directly linked to its ability to keep stakeholders positive about the company's current and future prospects. During a negative event or crisis situation, a company must ensure that it has effective strategies and resources in place to deal with it efficiently if it is to minimize losses in share price value and maintain a good corporate reputation. Indeed, if management is able to manage a crisis successfully, the company fares better both in terms of maintaining its share price value and its corporate reputation (Petersen, 2005).

Reputation capital has been considered an

\footnotetext{
*Corresponding author. E-mail: david.coldwell@wits.ac.za.
}

important competitive advantage that certain companies possess (Deephouse, 2000; Fombrun, 1996). Specifically, 'reputational capital' is defined as an organisation's stock of perceptual and social assets. In other words, the quality of the relationship the company has established with stakeholders and the regard in which both it and its brand are held (Fombrun and van Riel, 2004). Organisations accumulate reputational capital over time. In this regard, some writers use the metaphor of a bank account (Alsop, 2004; Dowling, 2002). A crisis will, in most cases, inflict some reputational damage in which reputational capital is lost (debit on the existing bank account). A favourable prior (pre-crisis) reputation (savings) acts as a buffer against reputational capital lost during a crisis. An organization with more reputational capital will have a stronger post-crisis reputation because it has more 'capital to spend', than an organization with an unfavourable or neutral pre-crisis reputation (Dowling, 2002; Alsop, 2004). As a result, it might be expected that a 
favourable pre-crisis reputation may result in an organisation suffering less and rebounding more quickly when confronted by a negative event. In this regard, Fombrun and van Riel (2004) report a number of event-based studies that support the reputational capital effect when examining stock price fluctuations (Gregory, 1998; Knight and Pretty, 1999).

Various accounting methods have been devised to measure intangibles associated with corporate value. For example, the Knowledge Capital Scoreboard (Lev, 2001) subtracts book values of corporate assets from their market value. In this regard, Forbes and Interbrand created indices of corporate reputation which they considered an aggregate intangible asset that must be evaluated using both internal and external information.

One measurement of such external information relating to the intangible asset of corporate reputation can be obtained through stakeholders'perceptions of the reputation capital of specific organizations. This is the approach adopted in the current study.

A definition of shareholders' value is: corporate value, minus debt. Or, to put it another way, a company's shareholder value is calculated as the present value of future cash flows of the business, discounted at its weighted average cost of capital, less the value of debt. However, a fundamental principle is that a company only adds value for its shareholders when equity returns exceed equity cost (Mars and Weir, 2000) and that a good 'rule of thumb' for this is a company's market share price at any given moment of time.

Although secondary research by the authors revealed that no previous research has been conducted in the South African context dealing specifically with associations between corporate crises, corporate reputation and share price values, recent empirical research conducted in the USA by Accenture (2011) suggests that the speed and quality of company responses to specific crises mitigates the effect on share price values and corporate reputation (http://www.accenture.com/,).

In line with the Accenture (2011) study and given the difficulties in managing different crises, this paper proposes a systematic action plan incorporating a stepwise ideal type model that embodies prescriptive remedial steps to be taken by management during and after a crisis situation. In order to assist crisis management, this paper proposes a structured, stepwise approach to the management of reputational risks. By analyzing a series of case studies of selected South African firms' responses to specific crises in comparison to an ideal type stepwise model, the study explores effects on specific share price values. Also, effects of reputation capital on share price value six months after the crises of each of the selected companies sustained are investigated. The core qualitative analytical tool is provided by an ideal type model based on information gathered by the actions taken by a company that has suffered attacks against its reputation over a series of crises it has confronted over its history, but which has successfully resolved by developing a stepwise approach that is regarded by many as an example of best international practice. This approach is used to analyze the completeness of the actions taken by the selected South African companies and their affects on share price values. The effects of accounting student and staff perceptions of the reputations of the selected companies on post crisis share price values and resolution are also analysed.

The study therefore aims to contribute to the extant literature by exploring:

(a) The effects of the post- crisis strategic remedial steps taken by the selected South African companies, compared to the best practice 'ideal type' model, on share prices and the speed of share price resolution and,

(b) The effects of reputation capital on post -crisis share price falls and speed of resolution.

To achieve this outcome, various recent case studies of South African companies that have experienced a crisis are used to test the efficacy of the proposed model in terms of post-crisis share price fluctuations. In addition, perceptions of the current reputations and brand strengths of selected South African companies by a sample of University accounting staff and students is used to test the effectiveness of reputation capital in buffering damage inflicted by such crises. This buffering effect is measured in terms of post-crises share price falls and resolutions for the selected companies.

\section{LITERATURE REVIEW}

\section{Events and crises}

For purposes of this paper, a crisis can be defined as a sudden and unexpected event that threatens to disrupt an organisation's operations and poses both a financial and reputational threat. Crises can harm stakeholders physically, emotionally and/or financially. For example, Klann's crisis model (2011: 5-7) offers a three level typology of crisis' severity in which a level 1 crisis involves company embarrassment but does not involve personal injury (level 2) or loss of life (level 3).

A wide range of stakeholders $\mathrm{can}$ be adversely affected by a crisis including community members, employees, customers, suppliers and shareholders. A crisis can threaten corporate reputation because it creates an organisational judgment platform. The news media and the internet play a critical role here as most stakeholders learn about specific crises from news reports. However, with many corporate crises most stakeholders learn about the event as it unfolds through online social media (Wartick, 1992). 
Exceptions would be actual victims or potential victims of a specific crisis who have experienced it either personally, or have been close enough to the crisis to be informed of it directly by the organisation. If corporate reputation shifts from favourable to unfavourable, because of the way a crisis has been dealt with, stakeholders may change how they interact with the organization concerned with negative changes undermining a favourable reputation which, in severe cases, may be lost entirely. In such instances, stakeholders may sever ties with an organization altogether and/or spread negative word of mouth commentary about the organisation (Coombs, 2007: 163; Rourke, 2004).

No company is immune to crises. Therefore, companies must prepare and able to respond immediately should a crisis occur. In other words, there must be a contingency plan in place to deal with the event effectively (Fombrun, 1996; Veysey, 2000).

An event can become a crisis, when it threatens a company's short-term prospects and possibly, with mismanagement, also its long-term survival. Companies rely on delicate interrelationships for their societal mandate to operate. When these relationships are jolted and profitability is threatened by an internally- or externally-generated crisis it is companies with strong reputations that act quickly and systematically to maintain stakeholder confidence that are most effective in guarding shareholder value (Sherman, 1999).

An event or crisis can impact on the valuation of a firm. According to the efficient market hypothesis, the share price of a company provides an unbiased estimate of a company's discounted stream of equity free cash flows per share. Research on the impact of a crisis on shareholders' share price reaction has been largely on the impact of earnings and dividends. However, some studies have examined the effects of accidental losses on firm value. For example, Angbazo and Narayanan (1996) show the impact of natural disasters upon propertyliability insurers' share values. A study by Sprecher and Pertl (1983) shows the impact of large accidental losses on the share price of a cross-section of industries in the United States. Marcus et al. (1987) studied the impact of automobile safety recall on measured share market reaction. Lamb (1995) examines the impact of actual natural and man- made disasters on property - liability insurers' stock values, but these have no bearing on the reputations of the companies involved.

\section{Reputation and reputation capital}

Fombrun (1996) defines reputation as "The net perception of a company's ability to meet expectations of all its stakeholders". A company's reputation tends to go hand in hand with its stakeholder 'image' (Bromley, 1993) that can be positive or negative. A company with a large reserve of reputational capital actually gains a competitive advantage against rivals as its reputation enables it to charge premium prices for its products, achieve lower marketing costs, and benefit from greater freedom in decision-making. In other words, reputation-building can be regarded as a form of enlightened self-interest (Fombrun, 1996: 21).

Identifying reputational drivers and risks means exploiting opportunities for reputation maintenance, enhancement, performance improvement and competitive advantage that add real value to the firm's bottom line (Rayner, 2003: 15). A positive and sustainable reputation is a major determinant of a business's future ability to generate wealth and succeed in the long term as corporate reputation is not only a measure of past performance, but also an indicator of future promise (Rayner, 2003: 16). The way an organisation deals with specific crises will affect existing reputation capital to a greater or lesser extent. Companies with significant existing reputational capital are less likely to sustain negative share price impacts.

In short, companies have to develop unique styles of doing business to rise above others in a similar industry and maintain a competitive reputation edge. It needs to continually monitor major stakeholders' expectations and ensure at least that a break-even point is reached where matching stakeholder expectations and actual delivery. When companies exceed stakeholders' expectations beyond break-even point, their reputations will be enhanced and their stock of reputation capital enlarged.

Although a firm's existing reputation capital can help it to ride out a particular storm, reputation should be protected during a crisis situation to safeguard it in the long run (Coombes, 2007). A good reputation among stakeholders arising from a company behaving proactively in the past can serve as a buffer during a crisis (Jones et al., 2000).

Researchers on reputation management have measured reputation by studying relations between its cognitive and affective aspects (Hall, 1992; Wartick, 2002). Affective reputation is based on emotions and sympathy (Shwaiger, 2004). Chambers (2001) states, strategic reputation management in a crisis is about avoiding negative and cherishing and projecting the positive. It entails the pro-active management of reputation risk and appropriate reactive responses to reputational opportunities and threats.

Fombrun (1996) suggests that assigning value to reputational capital is directly linked to how much a third party might pay to lease a corporate name. Licensing arrangements are actually royalty rates for corporate names that generally range between eight and fourteen percent of sales. Thus one estimate of the value of a company's reputation is the present value of all expected royalty payments over a given period. Fombrun (1996) 
also suggests an alternative approach to estimating a company's reputation is that of share prices which incorporate all known information about a company and fully reflect a company's future prospects.

As indicated earlier, establishing reputational capital helps a company cushion a blow during a crisis (Larkin, 2003). Alsop (2004) suggests that when companies build up "reputation capital" this can tide them over in turbulent times- like a savings account. Also, such firms suffer less damage and tend to rebound faster (Chambers, 2001). The ratio of a company's market value to its book value is sometimes used as an indicator of a company's accumulated pool of reputational and intellectual capital (Fombrun and Van Riel, 2004). When companies face crises, they generally lose market value. To some extent, the loss constitutes the stock market's best guess about the damage done to the company's future profitability that is, to its credibility and reputation. Companies with good reputations also show higher price/earnings ratios, which demonstrate that reputation is as much about future promise as it is about history (Larkin, 2003).

\section{Crisis management}

Much of the literature on crisis management per se, as distinct from reputation management, is based on a linear, sequential, strategic and tactical approach (Jaques, 2009; Burnett, 1988) similar to the approach adopted in this paper.

Fink (1986) developed a four stage crisis model, consisting of podromal, acute, chronic and resolution which became a template for other linear models. Hale et al. (2005) developed a spiral model in which the management of a crisis to progress "through a loop from observation through dissemination, triggering in turn another response iteration" is described (Jaques, 2009). An effective way of managing a crisis is to understand the crisis. Heath (1997) shows that crisis management is an integral part of issue's management. Studies by both Fink (1986) and Guth (1995) indicate that a small percentage of companies actually have an effective crisis plan of action. Brown (1993) showed in his research that most of the companies that did not have a contingency plan may go out of business within two years of suffering a major crisis (Jaques, 2007).

A number of models explaining crisis communication have been developed by researchers over the years. Barton (2001) showed that crisis situations can result in certain strategic action and that reactive strategies help minimize damage. If a crisis occurs and a company is caught unprepared or responds inappropriately, it may find its reputation in tatters (Rayner, 2003). Thus, when a crisis occurs, an important role for management is to ensure that the organization reacts, promptly. A prompt and carefully managed response made convincingly can entirely head off negative publicity (Chambers, 2001).
The role of a spokesperson during a crisis situation must be clearly defined because he/she represents the company's strategy during a crisis situation to the media (Lerbinger, 1997).

Companies must continually maintain their reputational capital. During an unusual event or crisis that impacts negatively on a company it should have carefully generated strategies in place to ensure it sustains minimal immediate reputation damage. Relationships between an organization and the media are particularly important during a crisis situation. Research has shown that effective communication can repair a company's image when threatened by a crisis situation (Benoit, 1997). Apology remains an important focal point of crisis communication (Coombes, 1999).

According to Fombrun (1996: 117), some companies over a period of time recover lost value quickly and the crisis fades. Others experience more extended damage. Research suggests that the difference lies in how a company handles the crisis and the strength of its existing reputation capital. Good reputations have considerable hidden value as a form of insurance - they act as a "reservoir of goodwill". The insurance value of reputation derives from its ability to buffer wellregarded companies from the detrimental effects of crisis situations. When faced with crises, companies need to handle them correctly and efficiently. In particular they need to ensure, inter alia, that:

(a) All information regarding the event is honest and that communication is transparent,

(b) The right spokespersons to deal with the media are selected,

(c) They are available to respond to queries, and

(d) They continually update the media, as well as the public about crisis developments and management.

Attempts to solve crises behind closed doors only make the public more suspicious and allow the media to speculate, sometimes negatively, on other issues.. On the other hand, it is possible if a crisis is handled well that may even enhance a company's existing reputation (Cawood, 1997). Accenture (2011) suggest that there are two basic approaches and four steps to high performance crisis management. Accenture (2011: 8) maintain that a combination of scenario planning and risk exposure analysis and identification consisting of four prescriptive remedial steps, best prepares companies to respond and take effective action in crisis situations. This stepwise approach to crisis management consists of:

(a) Preparing for unexpected failures through scenario planning,

(b) Ensuring crisis management operates effectively across horizontal and vertical structures and functions. Crises recognize no departmental or functional 
boundaries so an effective crisis management process must be pervasive across the company as a whole.

(c) Recognizing the crisis early and taking rapid decisive steps to manage it and,

(d) Communicating thoroughly, effectively and frequently with all audiences.

\section{Background to the problem}

In order to assist crisis management, this paper proposes a structured, stepwise approach to the management of reputational risks. By analyzing a series of case studies of selected South African firms' responses to specific crises in comparison to an ideal type stepwise model, the study explores the effects on specific share price values. The effect of reputation capital on share price value six months after the crises of each of the selected companies sustained is also investigated.

The core qualitative analytical tool is provided by an ideal type model based on information gathered by the actions taken by a company that has suffered attacks against its reputation over a series of crises it has confronted over its history, but which has successfully mitigated the consequences and minimized the damage by developing a stepwise approach that is regarded by many as an example of best international practice. This approach is then used to analyze the completeness of the actions taken by the selected South African companies and their affects on share price values. The main objectives of this paper are to:

(1) Determine the effects of the post- crisis strategic remedial steps taken by the selected South African companies, compared to the best practice 'ideal type' model, on share prices and the speed of share price resolution.

(2) Recommend a crisis management model that averts post-crisis share price falls and aids speed of share price resolution.

(3) Measure the effects of reputation capital on post-crisis share price falls and speed of resolution.

Various recent case studies of South African companies that have experienced recent crises are used to test the efficacy of the proposed model against post-crises share price fluctuations. In addition, perceptions of the current reputations and brand strengths of selected South African companies in a sample of University accounting staff and students is used to test the effectiveness of reputation capital in buffering damage inflicted by such crises. This buffering effect is measured in terms of postcrises share price falls and resolutions for the selected companies.

\section{METHODOLOGY}

The research design incorporates qualitative and quantitative approaches in a longitudinal design utilizing case studies and time series correlation analyses (Ghauri and Gronhaug, 2002). For the purpose of the qualitative research, a case study approach is used to generate a crisis management model. This model is based on an ideal type obtained from the extant literature and its efficacy tested (as measured by fluctuations in share prices over a six month period) with selected South African companies that have incorporated the stepwise approach it advocates to a greater or lesser extent. Yin (1994: 23) defines a case study as "an empirical enquiry that: 1 . Investigates a contemporary phenomenon within its real life context, especially when. 2. The boundaries between phenomenon and context are not clearly evident." The case study approach helps to obtain data from the case, as well as determine commonalities in steps taken in successful company crisis management.

Eisenhardt (1989) stresses that as in hypothesis testing research, the concept of a population is crucial because the population defines the set of entities from which the research sample is to be drawn. Thus the selection of cases is an important step in building theory from case study analysis. Multiple cases were used to increase the generality of the conclusions, and their external validity (Voss et al., 2002). In studying multiple cases, an important issue to consider is their selection. Cases should be selected according to clearly specified criteria, using replication logic. Yin (1994) states that replication logic means that cases must be selected either to predict similar results (literal replication) or to produce contrasting results, but for predictable reasons (theoretical replication). Replication logic is used in this research. Each case was selected on the basis of variables assumed to influence the degree of formalization (Meredith, 1998). An individual case study represents opportunities and unforeseen hazards which emerge when the specific case is held against an ideal type.

The ideal type approach originally developed by Max Weber can be used as a useful tool for comparative analysis and to develop an understanding of historical characteristics (Morrison, 2006). The ideal type is a construct which can be used for systematic comparative analysis of historical data analyzed on a case by case basis, which aims at presenting a logical explanation of a phenomenon. Weber created the ideal types as "explanatory schemes in order to understand individual case material taken from the 'infinite causal web of social reality'" (Morrison, 2006). Historical cases are explained compared and grouped together as similarities and differences between cases are realized. A particular case which represents all ideals is then chosen as the ideal type. The ideal type case epitomizes the case dynamics in the respective cluster. The cases are respectively compared to each other and to the ideal type within the group, from which certain characteristics are identified.

This comparison yields a dramatic variation of patterns which is summarized in the ideal type case. The ideal type defines what would be the features of an optimal case, because it reveals the structural dynamics in its structural pattern. Morrison (2006) explains that ideal type cases allow for explanations linking cases with structural patterns. Because social structures are realized to a variable degree in the cases in the data material, their typicality in relation to the ideal type case helps understand their structural versus individual developmental dynamics. Max Weber showed that ideal type analysis aims at measurement by stating that: "such concepts are constructs in terms of which we formulate relationships by the application of the category of objective possibility, by means of this category, the adequacy of our imagination oriented and disciplined by reality is judged". Weber's ideal type methodology used in qualitative research can help explain a specific case by making its unique dynamics understandable (Lewis-Beck et al., 2004). However, the process adopted in this study is more superficial in the sense that it uses a macro-analysis of steps taken by selected companies in 
accordance with the ideal type, but acknowledges that such macro measures fail to explain their intrinsic uniqueness in response to specifically different crises situations.

Construct validity requires the researcher to select the correct tool or method to operationalise the concepts being studied. Yin (1994) also states that, in order to address construct validity, the tactic is to establish and maintain a chain of evidence, which would allow an external observer to follow the derivative of evidence, from initial research questions to ultimate case study conclusions. In order to achieve construct validity, listed companies were selected as multiple sources of evidence, using the Johnson and Johnson case study as the "ideal type". This helped provide cross-validation by reference to the extant literature. Multiple sources of evidence were used in order to obtain construct validity. Sources used were relevant documents, such as media reports and journals. These documents were used to corroborate and augment evidence from other sources (Yin, 1994). Only recorded evidence was used to determine the evidence of the different case studies.

A research protocol contains the research instruments, the rules and general procedures for using the instruments, an indication of the sources of information, and a guide for case study reports (Yin, 1994). The elaboration of the research protocol in this study was the extensive use of media reports. In order to support the theory, two collection methods were used as the only appropriate alternatives: Archival sources and documentation. Interviews and observations were not possible due to the time frame of the case studies used. A questionnaire was devised to measure perceived corporate reputation and brand strength as a measure of corporate capital in the quantitative research. The questionnaire consisted of two items, brand name strength and corporate reputation, arranged on a ten-point semantic deferential scale ranging from 'very strong' to 'very weak' for each of the ten companies selected in the sample. Cronbach Internal consistency coefficients for the total scale were $0.744(n-22)$ and averaged for all eleven companies (including the ideal type Johnson and Johnson) $0.724(\mathrm{n}=2)$. This was considered an acceptable level of internal consistency for a two item scale. A non random sample consisting of 117 staff and students from the School of Accountancy at the University of Witwatersrand in Johannesburg were utilized for the study. Accounting staff and students were selected for convenience and also because they were regarded as being more likely to be familiar with the reputations of the selected South African companies. The criterion variables of share prices and speed of share price resolution were calculated in the following manner:

Average six month pre-crisis and post -crisis share prices for each company were calculated and, for comparability, pre and post crisis falls in share prices were expressed as percentages. Average share prices prior to the crisis were compared to share price falls in a two week window period immediately after the crisis. (The two week window being selected as it was felt this presented a reasonable time frame for market reaction). Size of share price resolution was measured by calculating average share prices for each company over six months and comparing it to pre-crisis average levels. Comprehensiveness of managerial actions in terms of the stepwise model and speed of crisis management implementation was measured by the total number of steps taken, multiplied by the number of steps taken within the post- crisis two week window period. Ten South African companies which experienced some form of crisis or event were chosen. Examples of South African companies selected were based on prior knowledge of a crisis affecting all the companies.

\section{The adoption of a crisis management ideal type and the development of a crisis management model}

Johnson and Johnson's subsidiary, McNeilab Incorporated introduced Tylenol, an aspirin-based medication, in 1961. Tylenol proceeded to become a very popular and profitable product for the company: It became the most popular pain reliever, thus monopolizing a large share of the market. However, in 1982, seven people in the Chicago area died after taking Tylenol, because the tablets had been laced with cyanide. It took the company weeks to determine whether the capsules had been tampered with during the manufacturing process or after leaving the factory (Kaplan, 1998). The company put on a massive corporate effort - from the chairman to marketing - in order to help resolve the crisis effectively. The company recalled 31 million bottles of Tylenol worth $\$ 100$ million, and sent 500000 letters, outlining the situation, to physicians, hospitals and Tylenol distributors. The company also set up a tollfree hotline for consumers to help resolve any queries. The skeptics had a field day predicting that the Tylenol brand would never recover. They were convinced that consumers would never see the name Tylenol in any form again, because the crisis had destroyed the Tylenol name. Eventually, a large investigation revealed that the capsules had been sabotaged outside, and not during, the manufacturing process (Kaplan, 1998).

After the crisis, Johnson and Johnson were faced with a dilemma. They had to find the best way to deal with the tampering, without destroying the reputation of their company, as well as that of their most profitable product, Tylenol. The company decided to re-launch the tarnished product. Due to the tampering incident, the Federal government of the United States of America required that manufacturers package all over-the-counter medicines in tamperresistant packages. Johnson and Johnson's packaging subsidiary, Mcneil, repackaged Tylenol with glued-end flaps, a plastic-neck seal, and an inner-foil seal, with a label instructing consumers not to use the product if its safety seals were broken. Although the government required only one of the three preventative measures, Johnson and Johnson did not want to take any chances and decided to include all three of the precautionary measures advised. Thereafter, the company launched a big production and distribution effort to make the newly packaged product available as soon as possible. This concept in packaging was innovative, and is now broadly used by food and pharmaceutical manufacturers globally (Govoni et al., 1986).

Johnson and Johnson were praised by the media for their swift and socially responsible actions. The incident provided the company with positive coverage for their handling of this crisis. Johnson and Johnson had to re-attract customers who could have possibly strayed from the brand as a result of the tampering. They also provided sales people from the company to make presentations to the medical community to reintroduce the product. Through the concerted effort of the company, Tylenol was reentrenched as a favourite with consumers. The success of the relaunch of the brand was based entirely on the quick actions of the corporation at the onset of the Tylenol crisis and the fact that it put public safety and interest first.

When the Tylenol crisis began and became more serious as time went by, Johnson and Johnson's top management turned to its basic corporate business philosophy for guidance. It was important for the company to be responsible in working for the public interest. The public and the medical community were alerted to the crisis, the food and drug administration was notified and the production of Tylenol was stopped (Neef, 2003).

A crucial decision by the directors which put Johnson and Johnson's public relations program in the right direction was for the company to co-operate fully with all types of news media. This was crucially important because the press, radio and television were imperative in warning the public of the ensuing danger. Without the help of the media, Johnson and Johnson's program would have been completely ineffective (Rayner, 2003).

The media performed the legwork for the company. There were numerous queries from the press about the Tylenol crisis, and every newspaper carried a story about it and television news 


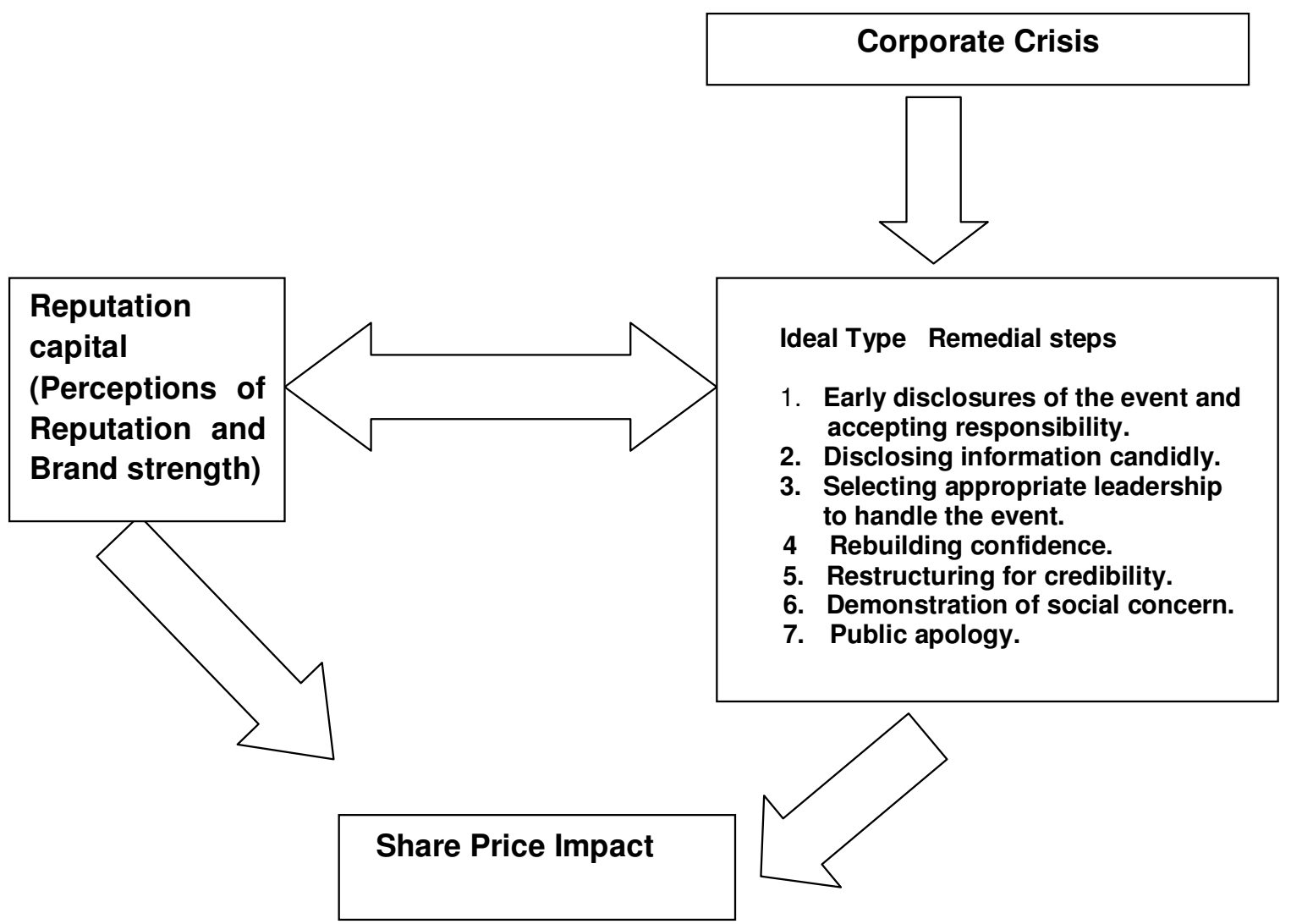

Figure 1. The crisis management model.

coverage on the crisis was as extensive. The widespread interest of the media exposed the vulnerability of the company's reputation to it (Kaplan, 1998). The media played a formidable role in Johnson and Johnson's successful public relations campaign following the crisis, but had it not fully co-operated with it, it would not have received positive media coverage with resultant potential damage to it reputation.

There are several key elements in the Johnson and Johnson case, namely: early disclosure and acceptance of responsibility(Chambers, 2001); disclosing information openly and explaining the crisis event (Fombrun, 1996); selecting appropriate leadership to handle the event (Fombrun, 1996); rebuilding confidence (Fombrun, 1996); restructuring for credibility (Fombrun, 1996); demonstrating social concern and apologizing for the crisis. These elements helped retain Johnson and Johnson's name as a reputable company. The above steps were used to develop a crisis management model incorporating the stepwise approach taken by Johnson and Johnson and to compare this "ideal type" with steps taken by selected South African companies in response to specific crises. A cross-case search strategy was used to search for patterns. Categories or dimensions were used to look for within-group similarities, coupled with intergroup differences; these dimensions were introduced through literature reviews. Some categories were apparent, whereas others were elusive and investigating similarities helped highlight differences between cases. Eisenhardt (1989) points out that search for similarity in a seemingly different pairs of cases can lead to a more sophisticated understanding of a phenomenon. Thus forced comparisons between cases can create new categories or factors which initially might have been overlooked.
During an unusual event or crisis that impacts a company; contingency plans should come into effect to ensure the company experiences minimum impact and sustains no longterm damage to its reputation. Management should therefore implement a crisis management strategy to help manage a given crisis situation. Figure 1 gives a graphical representation of the proposed crisis management model indicating a corporate crisis and its interrelationships with the ideal type model, reputation capital and share price impact.

Figure 1 indicates the postulated interrelationships between the variables. A crisis sets in motion a corporate reaction involving various steps to limit and control potential damage to the company concerned (indicated in Figure 1 by the arrow interlinking crisis with remedial steps taken by management). Reputation capital is built up through effective and responsible management, thus companies that endorse many or all of the seven major steps of the crisis management stepwise model can be expected to be those companies which have already generated such capital (thus the two-way arrow interlinking these variables). Similarly, both reputation capital and the endorsement of the crisis management model can be expected to have an impact on post-crisis share price values (indicated in Figure1 by arrows interlinking these variables).

\section{FINDINGS}

\section{Case study analysis}

The model developed from the Johnson and Johnson 
case study will now be applied to certain South African case studies. However, bearing in mind that each company develops a unique culture rooted in the country in which it operates and must adapt to the legislation required, certain unique factors become applicable when managing organizational crises in a South African context and these need to be taken account of in the model developed in this paper. Demonstration of social responsibility includes a manifestation of social concern. This step is a declaration of a company's social bona fides to the community which it serves, and which support it. Table 1 gives a succinct, tabulated overview of the stepwise crisis management approach taken by the selected South African companies.

Proactive steps such as early disclosures (Step 1) and disclosures which are openly given, transparent and complete (Step 2) are those that the company carries out when it is aware of an event that has occurred that will have a bearing on its reputation and market share value, and decides to take action before this is reported by the media. Apart from such early steps the seven steps indicated in the ideal stepwise model need not necessarily occur rigidly sequentially. For example, step.7, 'Public Apology' might occur earlier or later in the reactive steps taken to deal with a crisis.

\section{Correlation analysis}

The findings of a Spearman correlation analysis of number and speed of steps taken and perceptions of corporate reputations and brand strength (reputation capital) on average pre- and post-crisis share price fluctuations in the short-term (that is two weeks post crisis, and long-term (that is six months post crisis) of the selected South African are given in Table 2.

Table 2 indicates that number of steps taken is correlated with average pre-crisis and two week post crisis share price falls. $(R=-0.790, P=0.006)$. The negative correlation suggests that the larger the number of steps taken in conformance with the stepwise model, the smaller the average two weeks post crisis falls in share prices.

Table 2 also indicates that the number of steps taken and the speed with which they are taken in a two week window period post-crisis are associated with smaller average two week post -crisis share price falls for the ten selected companies $(R=-0.814, P=0.004)$ The negative correlation suggests that the greater the speed and number of steps taken in the two week post crisis period the smaller the average company share price falls. The correlations ( $R=0.612, P=0.060$ and $R=0.648, P=0.043$,) with pre/post crisis share price differences for average perceptions of corporate reputation and brand strength scores $(\mathrm{N}=117)$ respectively, indicate that the greater the company share price appreciation six months post-crisis, the greater the perception of its corporate reputation and brand strength.

\section{DISCUSSION OF THE FINDINGS}

The ideal type stepwise strategic model has shown through the case study analyses of ten South African companies that different strategies are implemented in response to specific crises. And that the South African companies selected have complied with the ideal type model to a greater or lesser extent. Although it is likely that at a phenomenological level of analysis each crisis experienced by a specific organization is unique and therefore not strictly amenable to analytical comparisons, each of the South African cases analyzed roughly conforms to Klann's (2003: 5-7). Level 1 company embarrassment crises that involve neither personal injury (Level 2) nor loss of life (Level 3).Quantitative instruments to measure perceptions of brand strength and corporate reputation have given some indication of the reputation capital associated with each of these companies.

The correlation analyses has tentatively indicated that the greater the number of steps taken by management in the companies concerned in conformance with the model, and the speed with which they are implemented, the smaller the post- crisis average share price fall .

The Accenture (2011) study notes that share price values fall post crises, because stakeholders feel that company responses are inadequate, after an initial plateau period of between two to six weeks. The current study found, In contrast, that share price reaction was almost immediate with measurable share price falls within a two week post-crisis period. It seems plausible that a rapid emotional reaction inducing a rapid share price fall precedes a more rational appraisal of the crisis which leads to a gradual share price resolution. This interpretation is supported by Klann (2003) who suggests that the immediate reaction by stakeholders to a company crisis is emotional which over the passage of time becomes more rational and dispassionate. The initial shareholder reaction to company crises, particularly from perceived company mismanagement, might therefore be expected to create a more pronounced immediate effect with a gradual return to normal share price levels over a more prolonged period of time.

Corporate capital as measured by perceptions of reputation and brand strength, are also found to be associated with greater company post-crisis share price resolution (that is, appreciation to average pre-crisis share price levels). This appears to support the earlier findings of Fombrun and van Riel, (2004: 32) who indicate the importance of reputation capital in cushioning an organization's reputation in post-crisis situations.

The Accenture (2011) study emphasizes the importance of a stepwise approach to company crises and runs parallel with the model suggested in the current study, although it gives less detail as to the content of 
Table 1. Shows the various steps taken by the selected South African companies in reaction to various crises.

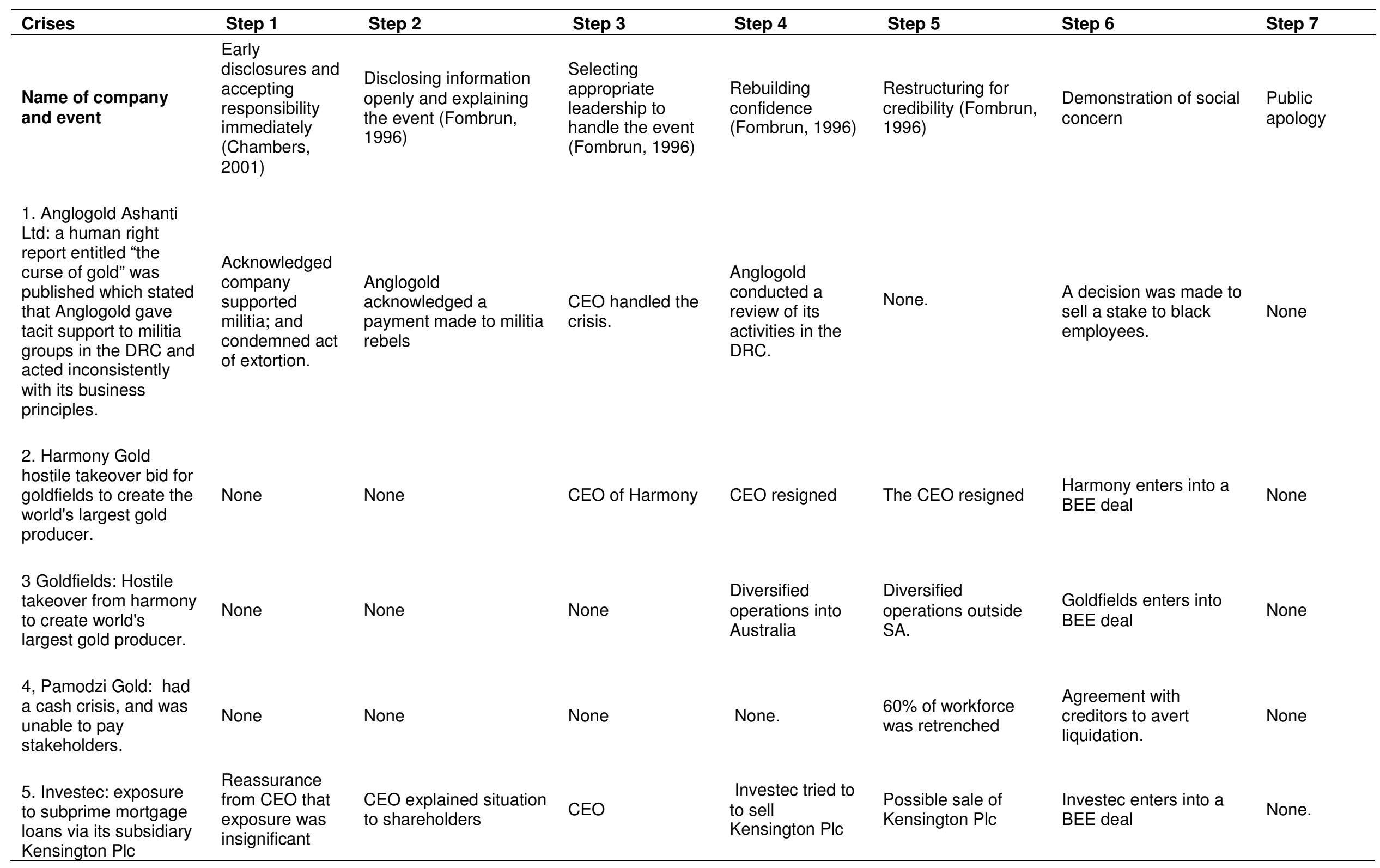


Table 1. Continued.

\begin{tabular}{|c|c|c|c|c|c|c|c|}
\hline $\begin{array}{l}\text { 6. Alexander forbes: } \\
\text { was making profits } \\
\text { from retirement funds } \\
\text { when they bulked bank } \\
\text { accounts to earn a } \\
\text { higher rate of interest } \\
\text { without declaring the } \\
\text { margins it made }\end{array}$ & None & None. & $\begin{array}{l}\text { CEO handled the } \\
\text { crisis }\end{array}$ & None & $\begin{array}{l}\text { Company brought in } \\
\text { a new CEO. }\end{array}$ & $\begin{array}{l}\text { Alexanderforbes had to } \\
\text { make a provision of } \\
\text { R480 million in its AFS. } \\
\text { A new black CEO was } \\
\text { appointed. }\end{array}$ & $\begin{array}{l}\text { CEO } \\
\text { apologizes } \\
\text { via a press } \\
\text { statement }\end{array}$ \\
\hline $\begin{array}{l}\text { 7. Vodacom: Former } \\
\text { Vodacom CEO and his } \\
\text { son, implicated in } \\
\text { Vodacom nepotism. }\end{array}$ & $\begin{array}{l}\text { CEO explains } \\
\text { crisis }\end{array}$ & $\begin{array}{l}\text { CEO responds to the } \\
\text { allegations }\end{array}$ & None & None & $\begin{array}{l}\text { Repurchase share } \\
\text { offer to save } \\
\text { administration costs. }\end{array}$ & $\begin{array}{l}\text { Vodacom enters into a } \\
\text { BEE deal }\end{array}$ & None \\
\hline $\begin{array}{l}\text { 8. MTN A merger to } \\
\text { create third largest } \\
\text { mobile phone company } \\
\text { was acrimoniously } \\
\text { called off. }\end{array}$ & $\begin{array}{l}\text { MTN gave } \\
\text { details on why } \\
\text { the merger was } \\
\text { called off. }\end{array}$ & $\begin{array}{l}\text { MTN did not inform } \\
\text { shareholders of the } \\
\text { status of the merger. }\end{array}$ & None & None & $\begin{array}{l}\text { CEO resigns, and } \\
\text { MTN negotiates to } \\
\text { buy another Cellular } \\
\text { company. }\end{array}$ & $\begin{array}{l}\text { MTN states its } \\
\text { commitment to enter } \\
\text { into a BEE deal. }\end{array}$ & None \\
\hline $\begin{array}{l}\text { 9. Sasol: is branded as } \\
\text { leader of a fuel price } \\
\text { fixing cartel operation } \\
\text { in the European } \\
\text { paraffin wax market. }\end{array}$ & $\begin{array}{l}\text { Statement } \\
\text { explaining the } \\
\text { price fixing of } \\
\text { paraffin }\end{array}$ & $\begin{array}{l}\text { Company made a public } \\
\text { statement. }\end{array}$ & Chairperson. & None. & $\begin{array}{l}\text { Suspends a number } \\
\text { of top managers } \\
\text { including CEO }\end{array}$ & $\begin{array}{l}\text { Sasol entered into a } \\
\text { BEE deal. }\end{array}$ & $\begin{array}{l}\text { CEO } \\
\text { apologizes } \\
\text { in AGM }\end{array}$ \\
\hline $\begin{array}{l}\text { 10. Tigerbrands Ltd } \\
\text { was fined R99 m by } \\
\text { Competition } \\
\text { Commission for } \\
\text { colluding with rivals to } \\
\text { raise bread prices }\end{array}$ & None & $\begin{array}{l}\text { Tiger Brands stated that } \\
\text { they had disciplined } 26 \\
\text { employees. }\end{array}$ & $\begin{array}{l}\text { CEO handled the } \\
\text { crisis }\end{array}$ & None & $\begin{array}{l}\text { Report by } \\
\text { Sonnenberg Inc } \\
\text { implicated senior } \\
\text { management; the } \\
\text { company had to } \\
\text { restructure the board }\end{array}$ & $\begin{array}{l}\text { Tiger Brands } \\
\text { cooperated with } \\
\text { Competition } \\
\text { Commission appointed } \\
\text { a new black CEO and } \\
\text { entered into a BEE } \\
\text { deal. }\end{array}$ & None. \\
\hline
\end{tabular}

the prescriptive steps to be used and does not base them on an empirically derived ideal type model. The Accenture (2011) study also does not empirically explore the effects of the number of steps taken or the speed with which they are implemented on share price values. These aspects, along with the differential buffering effects of perceived reputation capital of the selected South African companies, are found in the current study to be important independent variables in the effects of crises events on share price values and their subsequent resolution.

\section{CONCLUSIONS AND RECOMMENDATIONS}

The study has shown in a small sample of South
African companies that conformance to a strategic stepwise model of post -crisis management action that is taken speedily can reduce the effects of a crisis on company share price value. And, that share price resolution to pre-crisis levels is affected by perceptions of existing company reputation capital. The findings suggest that a strategy of prescriptive remedial steps in response to a specific corporate 
Table 2. Spearman rank correlations of associations between number of steps, speed of steps, perceptions of reputation capital and share price fluctuations.

\begin{tabular}{|c|c|c|c|c|c|c|}
\hline Variable & $\begin{array}{c}\text { No of steps } \\
\text { taken }\end{array}$ & $\begin{array}{c}\text { Number } X \text { speed of } \\
\text { steps taken }\end{array}$ & $\begin{array}{l}\text { Pre-crisis/two week } \\
\text { post -crisis average }\end{array}$ & $\begin{array}{c}\text { Before /after average } \\
\text { share price difference }\end{array}$ & $\begin{array}{c}\text { Average perception of } \\
\text { corporate reputation scores }\end{array}$ & $\begin{array}{l}\text { Average perception of } \\
\text { brand strength scores }\end{array}$ \\
\hline \multirow{3}{*}{$\begin{array}{l}\text { Number of } \\
\text { steps taken }\end{array}$} & 1.000 & $0.965^{\star *}$ & $-0.790^{\star *}$ & -0.100 & 0.282 & 0.276 \\
\hline & & 0.000 & 0.006 & 0.783 & 0.429 & 0.440 \\
\hline & 10 & 10 & 10 & 10 & 10 & 10 \\
\hline \multirow{3}{*}{$\begin{array}{l}\text { Number } X \text { speed of } \\
\text { steps taken }\end{array}$} & $0.965^{\star *}$ & 1.000 & $-0.814^{* *}$ & -0.205 & 0.242 & 0.217 \\
\hline & 0.000 & . & 0.004 & 0.570 & 0.500 & 0.546 \\
\hline & 10 & 10 & 10 & 10 & 10 & 10 \\
\hline \multirow{3}{*}{$\begin{array}{l}\text { Pre crisis/two week } \\
\text { post crisis average\# }\end{array}$} & $-0.790^{\star *}$ & $-0.814^{\star *}$ & 1.000 & 0.188 & -0.164 & -0.188 \\
\hline & 0.006 & 0.004 & . & 0.603 & 0.651 & 0.603 \\
\hline & 10 & 10 & 10 & 10 & 10 & 10 \\
\hline \multirow{3}{*}{$\begin{array}{l}\text { Before /after average } \\
\text { share price difference }\end{array}$} & -0.100 & -0.205 & 0.188 & 1.000 & 0.612 & $0.648^{*}$ \\
\hline & 0.783 & 0.570 & 0.603 & . & 0.060 & 0.043 \\
\hline & 10 & 10 & 10 & 10 & 10 & 10 \\
\hline \multirow{3}{*}{$\begin{array}{l}\text { Average perception of } \\
\text { corporate reputation } \\
\text { scores }\end{array}$} & 0.282 & 0.242 & -0.164 & 0.612 & 1.000 & $0.976^{\star *}$ \\
\hline & 0.429 & 0.500 & 0.651 & 0.060 & . & 0.000 \\
\hline & 10 & 10 & 10 & 10 & 10 & 10 \\
\hline \multirow{3}{*}{$\begin{array}{l}\text { Average perception of } \\
\text { brand strength scores }\end{array}$} & 0.2760 & 0.217 & -0.188 & $0.648^{*}$ & $0.976^{\star \star}$ & 1.000 \\
\hline & 0.440 & 0.546 & 0.603 & 0.043 & 0.000 & . \\
\hline & 10 & 10 & 10 & 10 & 10 & 10 \\
\hline
\end{tabular}

** Correlation is significant at the 0.01 level (2-tailed); ${ }^{*}$ Correlation is significant at the 0.05 level (2-tailed). 
crisis and the speed with which it is implemented and the careful nurturing of corporate reputation may allow companies to minimize post-crisis damage to share price values. Limitations to the study include:

(1) Every corporate crisis is qualitatively different and at a certain level of analysis even unique.

(2) Perceptions of reputation/brand strength were taken post- crises.

(3) The samples were small and non-randomly selected.

(4) Shareholder reactions to crises are affected by many factors and thus some factors are likely to be left unexplored by the focused stepwise crisis management model.

(5) The correlation analysis cannot provide a causal or causal directional explanation.

However, all crises considered were found to affect company share prices, and average falls and appreciations were considered over both short and long terms in terms of both the number and speed of remedial steps taken in conformance with the model. The findings are highly plausible and are supported further by the associations found between share price values and reputation capital. Future studies could fruitfully pursue this model in other contexts with larger samples.

\section{REFERENCES}

Accenture (2011). Corporate Crisis Management. Available: http://www.accenture.com (Accessed: 9 May, 2011).

Alsop JR (2004). The 18 Immutable Laws of Corporate Reputation. Kogan Page.UK, 211-220.

Angbazo LA, Narayanan R (1996). Catastrophic Shocks in the Property-Liability Insurance Industry: Evidence on Regulatory and Contagion Effects. J. Risk Insur., p. 63.

Barton L (2001). Crisis in organizations II. 2nd Edition. College Divisions South Western, Cincinnati. OH, 103-127.

Benoit W (1997). Image repair discourse and crisis communication. Publ. Relat. Rev. 23(2): 177-186.

Bromley DB (1993). Reputation, image and impression management. John Wiley and Sons. Chichester. UK, 240-252.

Brown M (1993). The Disaster Business. Management Today, October: $42-48$.

Burnett JJ (1988). A Strategic Approach to Managing Crises. Publ. Relat. Rev., 24(4): 475-488.

Caywood CL (1997). The Handbook of Strategic Public Relations and Integrated Communications. NY. Mcgraw Hill, 189-190.

Chambers P (2001). Reputational Risk - the new internal audit paradigm. http://www.management-audit.com (Accessed 20-012010).

Coombs T (1999). Ongoing crisis communication. Planning, managing, and responding. Thousand Oaks: SAGE Publications, 121-123.

Coombs T (2007). Protecting organization reputations during a crisis. The development and application of Situational Crisis Communication Theory. Corp. Rep. Rev., 10(3): 163-176.

Deephouse D (2000). The Term "Reputation Management": Users, Uses and the trademark tradeoff. Corp. Rep. Rev., 5(1): 9-18.

Dowling G (2002). Creating corporate reputations. Identity, image and performance. Oxford: Oxford University Press, p. 23.

Eisenhardt KM (1989). Building theories from case study research. Acad. Manage. Rev., 14(4): 532-550.

Fink S (1986). Crisis Management: Planning for the Inevitable. American Management Association. New York.

Fombrun JC (1996). Reputation, realising value from the corporate image. Harvard Business School Press. USA.
Fombrun C, Van Riel CBM (2004). Fame and Fortune: How Successful companies build winning reputations. Prentice Hall. USA, 26-39.

Ghauri P, Gronhaug K (2002). Research Methods in Business Studies, Essex, Pearson Education Limited, 57-182.

Govoni N, Eng R, Galper M (1986). Promotional Management. Englewood Cliffs, N.J: Prentice-Hall, 470-471.

Gregory JR (1998). "Does corporate reputation provide a cushion to companies facing market volatility? Some supportive evidence". Corp. Rep. Rev., 1:288-290.

Guth DW (1995). Organizational crisis experience and public relations roles. Publ. Relat. Rev., 21: 123-137.

Hale JE, Dulek RE, Hale DP (2005). Crisis Response Communication Challenges: Building Theory from Qualitative Data. J. Bus. Commun., 42(2): 112-134.

Hall R (1992). The strategic analysis of intangiable ressources. Strat. Manage. J., 13(2): 135-144.

Heath RL (1997). Strategic Issues Management: Organizations and Public Policy Challenges. SAGE: Thousand Oaks, CA.

Jaques T (2007). Issue Management and Crisis Management: An Intergrated, non-linear, relational construct. Publ. Relat. Rev., 33(2): 147-157.

Jaques T (2009). Issue management as a post-crisis discipline: Identifying and responding to issue impacts beyond the crisis. J. Publ. Aff., 9(1): 35-44.

Jones G, Jones B, Little P (2000). Reputation as reservoir: Buffering against loss in times of economic crisis. Corp. Rep. Rev., 3(1): 21-29.

Kaplan T (1998). The Tylenol crisis. Available: http://www.personal.psu.edu/users/w/x/wxk116/tylenol/crisishtml (Accessed: October 2009).

Klann G (2003). Crisis Leadership. Center for Creative Leadership Press, USA.

Knight RF, Pretty DJ (1999). Corporate Catastrophes, Stock Returns and Trading Volumes. Corp. Rep. Rev., 2(4): 363-378.

Lamb RP (1995). An Exposure Based Analysis of Property- Liability Insurer Stock Values around Hurricane Andrew. J. Risk Insur., p. 62.

Larkin J (2003). Strategic Reputation. Palgrave Macmillan, USA, 37-86.

Lerbinger O (1997). The crisis manager. Facing risk and responsibility. Mahwah: Lawrence Erlbaum Associates.

Lev B (2001). Intangibles: Management, Measurement and Reporting. Brookings Institution Press. Washington, DC

Lewis-Beck MS, Bryman A, Liao TF (2004). The Sage encyclopedia of social science research methods, Vol. 1. SAGE, p. 310.

Marcus AA, Bromley P, Goodman R (1987). Preventing Corporate Crisis: Stock Market Losses as a deterrent to the Production of Hazardous Products. Columbia J. World Bus, Spring.

Mars G, Weir D (2000). Risk Management. Aldershot, England.

Meredith J (1998). Building operations management theory through case and field research. J. Oper. Manage., 16: 441-454.

Morrison KL (2006). Marx, Dirkheim and Weber: Formations of Modern Social Thought. 2nd Edition. SAGE, 438.

Neef D (2003). Managing Corporate Reputation and Risk. Butterworth. USA.

Petersen G (2005). Managing Reputation Risk: Creating an Effective risk structure Part II. Available: http://www.boardmember.com/network/index.pl?section=1028\&article id $=12260 \&$ show=article (Accessed: 5 July 2010).

Rayner J (2003). Managing Reputational Risk. John Wiley. UK. 101173.

Rourke M (2004). Protecting your reputation. Risk Manage. J., 51: (5):40-44.

Sherman ML (1999). AIG Europe (UK), Institute of Director's guide. Management: Strategies for protecting companies their brands and their directors. Directors Publications.

Schwaiger M (2004). Components and parameters of corporate reputation - an empirical study. Schmal Bus. Rev., 56(1): 46-71.

Sprecher CR, Pertl MA (1983). Large Losses, Risk Management and Stock Prices. J. Risk Insur., 50: 107-117.

Veysey S (2000). Reputation Risk needs managing. Bus. Insur., 34 (25): 21-22.

Voss CA, Tsikriktsis N, Frohlich M (2002). Case study research in operations management. Int. J. Oper. Prod. Man., 22(2): 195-219. 
Wartick S (1992). The Relationship between Intense Media Exposure and Change in Corporate Reputation. Bus. Soc., 31(1): 33-49.

Wartick S (2002). Measuring corporate reputation. Definition and data. Bus. Soc., 41(4): 371-392.
Yin RK (1994). Case Study Research. $2^{\text {nd }}$ edition. SAGE Publications, USA, p. 23. 